\title{
Respiratory rhythm generation: triple oscillator hypothesis
}

\section{[version 1; peer review: 3 approved]}

\author{
Tatiana M. Anderson 1,2, Jan-Marino Ramirez (D1,3 \\ ${ }^{1}$ Center for Integrative Brain Research, Seattle Children's Research Institute, Seattle, WA, USA \\ ${ }^{2}$ Graduate Program for Neuroscience, University of Washington School of Medicine, Seattle, WA, USA \\ ${ }^{3}$ Department of Neurological Surgery and Pediatrics, University of Washington School of Medicine, Seattle, WA, USA
}

V1 First published: 14 Feb 2017, 6(F1000 Faculty Rev):139

https://doi.org/10.12688/f1000research.10193.1

Latest published: 14 Feb 2017, 6(F1000 Faculty Rev):139

https://doi.org/10.12688/f1000research.10193.1

\section{Abstract}

Breathing is vital for survival but also interesting from the perspective of rhythm generation. This rhythmic behavior is generated within the brainstem and is thought to emerge through the interaction between independent oscillatory neuronal networks. In mammals, breathing is composed of three phases - inspiration, post-inspiration, and active expiration - and this article discusses the concept that each phase is generated by anatomically distinct rhythm-generating networks: the preBötzinger complex (preBötC), the post-inspiratory complex (PiCo), and the lateral parafacial nucleus $\left(\mathrm{pF}_{\mathrm{L}}\right)$, respectively. The preBötC was first discovered 25 years ago and was shown to be both necessary and sufficient for the generation of inspiration. More recently, networks have been described that are responsible for post-inspiration and active expiration. Here, we attempt to collate the current knowledge and hypotheses regarding how respiratory rhythms are generated, the role that inhibition plays, and the interactions between the medullary networks. Our considerations may have implications for rhythm generation in general.

\section{Keywords}

Respiration, breathing, rhythm generation, networks, pacemaker, preBotzinger complex, Oscillators, Postinspiration

\section{Open Peer Review}

Approval Status
1

\section{version 1}

14 Feb 2017

Faculty Reviews are review articles written by the prestigious Members of Faculty Opinions. The articles are commissioned and peer reviewed before publication to ensure that the final, published version is comprehensive and accessible. The reviewers who approved the final version are listed with their names and affiliations.

\section{Muriel Thoby-Brisson, Institut de} Neurosciences Cognitives et Intégratives d'Aquitaine, CNRS UMR 5287, Université de Bordeaux, Bordeaux, France

2. Jose Fernando Pena-Ortega, Universidad Nacional Autónoma de México-Campus Juriquilla, Querétaro, Mexico

3. Richard Wilson, University of Calgary, Calgary, Canada

Any comments on the article can be found at the end of the article. 
Corresponding author: Jan-Marino Ramirez (nino1@uw.edu)

Competing interests: The authors declare that they have no competing interests.

Grant information: The author(s) declared that no grants were involved in supporting this work.

Copyright: (c) 2017 Anderson TM and Ramirez JM. This is an open access article distributed under the terms of the Creative Commons Attribution License, which permits unrestricted use, distribution, and reproduction in any medium, provided the original work is properly cited.

How to cite this article: Anderson TM and Ramirez JM. Respiratory rhythm generation: triple oscillator hypothesis [version 1; peer review: 3 approved] F1000Research 2017, 6(F1000 Faculty Rev):139 https://doi.org/10.12688/f1000research.10193.1

First published: 14 Feb 2017, 6(F1000 Faculty Rev):139 https://doi.org/10.12688/f1000research.10193.1 


\section{Introduction}

Rhythms and oscillations function at the core of many brain processes $^{1,2}$. For example, rhythmic spinal circuits control locomotor gait $^{3,4}$, thalamic oscillations detect attentional state ${ }^{5,6}$, cerebellar rhythms are important for motor coordination ${ }^{7,8}$, and circadian rhythms entrain our biological clocks to a 24-hour cycle ${ }^{9,10}$. Compared to these circuits, respiratory neural networks in the brainstem offer a uniquely advantageous system in which to study rhythm generation because of (1) the known anatomical location of respiratory rhythm generators ${ }^{11-15}$ and (2) the ability to reduce the breathing network into various levels in preparations that retain robust and autonomous rhythmic output ${ }^{11,15-18}$. As a result, the control of respiration can be studied from the molecular to the systems level. Mammalian respiration consists of three phases: inspiration, post-inspiration, and active expiration ${ }^{19,20}$. The networks that collectively generate the three respiratory phases are distributed bilaterally in the ventral respiratory column (VRC) of the brainstem ${ }^{21-23}$.

Within the VRC, the first described respiratory neural network, the preBötzinger complex (preBötC), is both necessary and sufficient for the generation of inspiration ${ }^{11,24-27}$. The preBötC can singularly reconfigure to produce the inspiratory phase of eupnea (normal breathing), gasps, and sighs ${ }^{28}$. The respiratory rhythm generated within the preBötC is dependent on excitatory mechanisms, and the location of the network within the ventrolateral medulla has been identified in rodents ${ }^{11,29}$, cats $^{26}$, and humans ${ }^{30}$. Rhythm-generating, glutamatergic, and bilaterally interconnected preBötC interneurons are derived from progenitors that express the homeobox gene $D b x 1^{25,31}$. The preBötC can be isolated in an in vitro transverse slice that retains fictive inspiratory bursts in phase with inspiratory hypoglossal motor output ${ }^{11}$. The transverse slice is amenable to rigorous electrophysiological, histochemical, and optogenetic manipulation. Recently, two distinct rhythm generators have been described that are hypothesized to control the other two phases of respiration: the post-inspiratory complex ( $\mathrm{PiCo})$ for the control of post-inspiration, and the lateral parafacial nucleus $\left(\mathrm{pF}_{\mathrm{L}}\right)$, a subpopulation within the retrotrapezoid nucleus parafacial respiratory group (RTN/pFRG), for the control of active expiration (Figure 1). In addition to the previously mentioned transverse in vitro slice ${ }^{12,32,33}$, en-bloc brainstem-spinal cord ${ }^{31,34,35}$, in situ $^{36}$, sagittal slab ${ }^{17,37}$, and, most recently, horizontal slice ${ }^{15}$ preparations offer further accessibility and tractability to begin to unravel how the three phases of breathing are generated and interconnected.

\section{Mammalian respiratory rhythmogenesis}

Decades of research have revolved around the endeavor to unmask the underlying processes controlling inspiratory rhythm generation $^{11,28,38}$. Indeed, a long-standing question in the respiratory control field queries how rhythmic, inspiratory activity in the brainstem emerges from the interaction between intrinsic cellular properties and circuit-based synaptic properties. Amid many theories, the answer remains unresolved, but it is likely that multiple rhythmogenic mechanisms exist within the functionally and molecularly heterogeneous preBötC population, and these mechanisms may vary depending on the metabolic, behavioral, and environmental conditions of the organism ${ }^{39}$.

Frequently, models of neural rhythmogenesis include autonomously bursting neurons (pacemakers, or endogenous bursters) as contributors to rhythmogenesis ${ }^{40-43}$. Endogenous bursting neurons have been described in numerous rhythm-generating networks and the respiratory network is not an exception ${ }^{43,44}$. Approximately $20 \%$ of preBötC neurons can be classified as pacemakers, as defined by their tendency to burst in the absence of synaptic input at a period and burst duration similar to the duty cycle of the in vitro respiratory rhythm ${ }^{38,45-47}$. Pacemaker neurons in the preBötC can be either

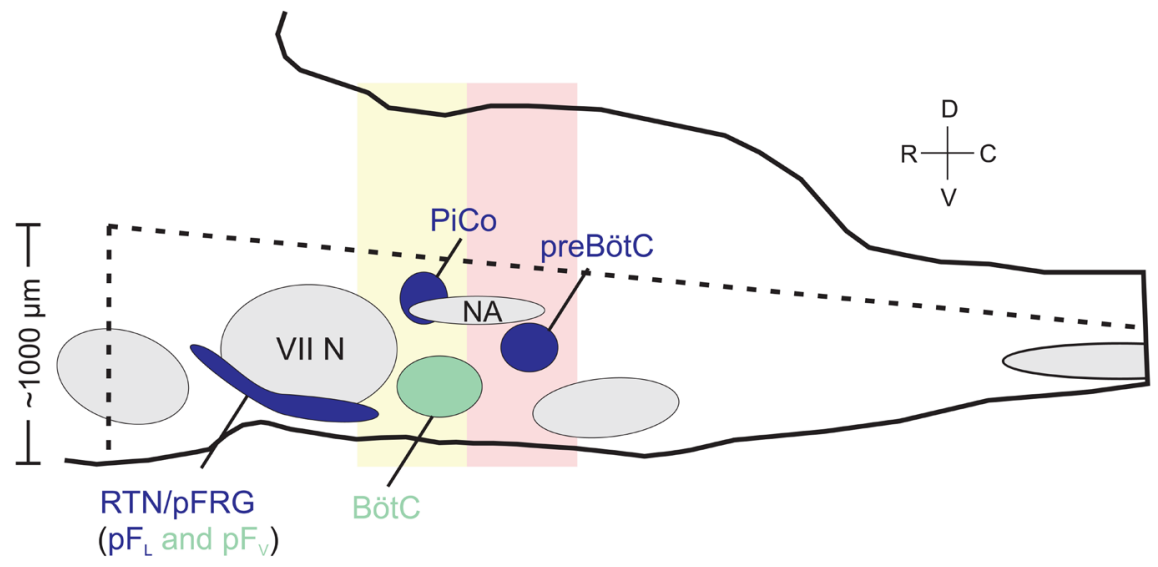

Figure 1. Anatomical map of oscillators in the ventral respiratory column. Schematic of the brainstem from a sagittal view illustrating the approximate anatomical locations of the three respiratory rhythm generators. Shapes in blue represent the three distinct oscillators (preBötzinger complex [preBötC], post-inspiratory complex [PiCo], and retrotrapezoid nucleus parafacial respiratory group [RTN/pFRG]) that are thought to individually control the three phases of respiration. The RTN/pFRG is further segregated into the lateral parafacial nucleus $\left(\mathrm{pF}_{\mathrm{L}}\right)$, which is more lateral, dorsal, and rhythmogenic, and the ventral parafacial nucleus $\left(\mathrm{pF}_{\mathrm{v}}\right)$, which is more medial, ventral, and not considered rhythmogenic. Shapes in gray represent motor nuclei, specifically VII N = facial nucleus and NA = nucleus ambiguus. Green represents neuronal populations that contribute to the respiratory rhythm but are not thought to be independent rhythm generators. The dotted lines indicate the approximate boundaries of the horizontal slice, while the pink and yellow boxes illustrate the approximate boundaries of transverse slices isolating preBötC and $\mathrm{PiCo}$, respectively. 
glutamatergic ${ }^{38,46}$ or glycinergic ${ }^{48}$. The "pacemaker hypothesis", in its strictest interpretation, is the idea that excitatory pacemaker cells play an obligatory role in driving the inspiratory rhythm. It is supported by studies in which antagonists of the persistent sodium current $\left(\mathrm{I}_{\mathrm{NaP}}\right.$; riluzole $)$ and the calcium-activated nonspecific cationic current $\left(\mathrm{I}_{\mathrm{CAN}}\right.$; flufenamic acid $\left.[\mathrm{FFA}]\right)$, the two mechanisms underlying bursting in preBötC neurons, block fictive inspiration in vitro ${ }^{49}$ and inspiration in vivo ${ }^{50}$. Moreover, regions such as the preBötC and the RTN/pFRG, that are known to have rhythmogenic functions, are rich in endogenous bursters ${ }^{37}$. The exact role of endogenously bursting neurons in respiratory rhythm generation is still a matter of debate $38,40,43-45,47,51,52$. However, it is generally agreed that these bursting neurons do not act as simple "pacemakers" that drive the rhythm. Instead, these neurons are well integrated within the respiratory network, and synaptic and other ionic mechanisms contribute to their timing and discharge properties ${ }^{39,40,53,54}$.

Although cellular properties have been identified that differentiate pacemaker from non-pacemaker neurons ${ }^{55,56}$, we shouldn't think of these in a binary manner. Instead, bursting and non-bursting lie on a continuum of firing characteristics from weak tonic firing to strong bursting $^{53}$, consistent with the hypothesis that preBötC neurons exhibit a continuous distribution of membrane conductances ${ }^{57-59}$. For example, $\mathrm{I}_{\mathrm{CAN}}$ and $\mathrm{I}_{\mathrm{NaP}}$ currents are not exclusive to endogenous burster neurons but are present on many, if not the entire population of, preBötC inspiratory neurons in vitro ${ }^{45,46,59,60}$. The "group pacemaker" theory posits that activity of tonically firing, glutamatergic preBötC neurons can percolate and increase in activity by means of positive feedback ${ }^{47,61}$. The pre-inspiratory phase occurs when the positive feedback has surpassed other network constituents and recurrent excitation leads to the initiation of a synchronized inspiratory burst ${ }^{62}$.

This idea was further tested by using in vitro physiological data and modeling techniques to hypothesize that each individual population burst is driven by a dynamic, stochastic, and flexible assembly of preBötC neurons within a sparsely connected network ${ }^{63}$. Insights into the physiology of the sparsely connected network can be performed by multi-array recordings ${ }^{64}$. Using this technique, Carroll et al. estimated a $1 \%$ functional connectivity between preBötC neurons ${ }^{63}$, a figure much lower than another study that estimated a $13 \%$ probability of one-way excitatory connectivity from dual whole-cell patch recordings of visualized, closely located preBötC neurons ${ }^{65}$. Reasons for the order of magnitude discrepancy in connectivity estimates have yet to be reconciled other than obvious differences in approach and preparation.

Rhythm generation and pattern generation have been suggested to be separable phenomena ${ }^{66-68}$. Rhythm generation refers to the generation of timing signals; however, the control of the timing and coordination of muscle activity is referred to as pattern generation ${ }^{66,69,70}$. Intracellular burst activity and motor outputs can exhibit a variety of shapes such as decrementing, augmenting, or bell-shaped ${ }^{16,71}$. Under conventional perfusion conditions in vitro, preBötC bursts follow a 1:1 ratio with hypoglossal motor output ${ }^{16}$. However, when excitability is lowered with decreased concentrations of extracellular potassium, burst frequency decreases ${ }^{27,72}$. When a burst is expected, Feldman and colleagues instead observe "burstlets" that are small in amplitude and do not produce a motor output signal. Burstlets appear at multiples of the shortest interburst interval (i.e. are quantized) and can also be observed under specific conditions in vivo ${ }^{66}$. The authors hypothesize that these burstlets represent preinspiratory activity that triggers inspiratory bursts when a certain, undefined threshold is reached.

In addition to the preBötC, two other respiratory microcircuits have been identified that function as independent oscillators controlling the other two phases of breathing: post-inspiration and active expiration ${ }^{14,15,73}$. Under physiological conditions, expiration is a passive process and mammals largely alternate their breathing between inspiration and post-inspiration ${ }^{74}$. Located rostral to the preBötC and dorsomedial to the nucleus ambiguus, the PiCo was recently identified as the putative site for the generation of post-inspiratory activity $^{15}$. Similar to the preBötC, PiCo rhythms are also dependent on non-NMDA, excitatory mechanisms ${ }^{15}$. Thus, it is likely that the two populations employ similar rhythm-generating mechanisms. Interestingly, one study completed in goats showed that the gradual ablation of the preBötC over the course of two weeks does not result in breathing abnormalities, at least in this species, suggesting that plasticity mechanisms are able to compensate if time is allowed for brainstem networks to reconfigure ${ }^{75}$. Perhaps PiCo neurons are logical candidates for assuming the preBötC's role?

During periods of higher metabolic activity, for example during exercise, a third phase of breathing is recruited during late expiration, called active expiration, that is required to breathe air out more forcibly than under rest conditions. The active expiratory rhythm reportedly originates in the $\mathrm{pF}_{\mathrm{L}}{ }^{13,14}$. This area is defined as a conditional but independent oscillator owing to the observation that it is active only under certain conditions ${ }^{73}$ but can generate rhythmic motor output from facial motor roots in the presence of an opioid agonist, DAMGO ${ }^{76}$. Similar to the preBötC and PiCo, the $\mathrm{pF}_{\mathrm{L}}$ is dependent on excitatory mechanisms ${ }^{35,77}$. Further studies are required to fully elucidate the rhythmogenic mechanisms of these three excitatory oscillatory networks.

\section{Role of inhibition}

While it is generally accepted that the preBötC can burst autonomously in vitro, even when inhibition is blocked pharmacologically $^{11}$, the role of inhibition within the intact respiratory network is still debated. Originally, it was proposed that inspiration and expiration were generated by "half-centered oscillators" in which one population of neurons reciprocally inhibits the other population to generate an alternating two-phase breathing rhythm ${ }^{78}$. However, these hypotheses have not been rigorously tested by specifically manipulating identified populations of neurons.

A population termed the Bötzinger complex (BötC) was discovered to contain primarily inhibitory neurons including post-inspiratory and augmenting expiratory neurons ${ }^{79-81}$. Additionally, approximately $50 \%$ of the neurons that make up the preBötC are inhibitory, mostly glycinergic, interneurons ${ }^{82}$. A contemporary model posits an "inhibitory connectome" or "inhibitory ring" hypothesis in which reciprocal inhibition between the preBötC and other brainstem circuits, such as the BötC, produce the three phases of breathing ${ }^{83,84}$. The theory states that glycinergic inhibition resets the activity of 
inspiratory, post-inspiratory, and expiratory neurons in the ventral respiratory network ${ }^{84}$. These interpretations are derived mainly from intracellular recordings in vivo or in situ paired with computational modeling (for reviews see ${ }^{18,79,84,85}$ ).

However, some aspects of this theory have been considered controversial. The inhibitory ring model would predict that blocking inhibition in the preBötC or the BötC would result in apnea, or cessation of breathing. When Feldman and colleagues tested this by pharmacologically injecting glycinergic and $\mathrm{GABA}_{\mathrm{A}}$ receptor antagonists into the preBötC and BötC in vagotomized rats, they observed little to no effect on the breathing rhythm ${ }^{86}$. They concluded that inhibition is not obligatory for rhythm generation but instead contributes to shaping the pattern of the rhythmic output. Of note, however, the injection of somatostatin, an inhibitory neuropeptide, into the BötC region resulted in the specific elimination of post-inspiratory vagal motor output ${ }^{87}$.

These experiments were done under the assumption that the BötC was responsible for the generation of post-inspiration. However, as briefly mentioned above, it was recently discovered that the PiCo provides a necessary excitatory drive for the generation of post-inspiratory activity ${ }^{15}$. The novel horizontal slice, described by Anderson et al., keeps the entire medullary VRC intact, and thus, using this preparation, one can simultaneously record fictive inspiratory bursts (from the preBötC) that are immediately followed by fictive post-inspiratory bursts (from the PiCo) ${ }^{15}$ (Figure 1). The PiCo rhythm persists in the absence of inhibition when the network is isolated in a transverse in vitro slice immediately rostral to the conventional transverse preBötC slice $^{15,88}$ (Figure 1). This is similar to the persistence of the preBötC rhythm in the absence of synaptic inhibition in vitro ${ }^{89-91}$. Similar to the in vivo experiment by Burke et al..$^{87}$, the PiCo rhythm was specifically abolished upon the application of somatostatin, with little to no change in the preBötC rhythm. Further experiments are necessary to fully elucidate the role of inhibition between respiratory rhythms in vivo.

\section{Interactions between oscillators}

To truly understand how respiration is generated, it is imperative to ascertain the interactions between the different rhythm generators. While this work is far from complete, some progress has been made studying the interactions between the preBötC and the $\mathrm{pF}_{\mathrm{L}}$ as well as interactions between the preBötC and the PiCo.

At embryonic day 14.5 (E14.5), before the preBötC is active, the $\mathrm{pF}_{\mathrm{L}}$ is rhythmic ${ }^{35}$. A day later, at $\mathrm{E} 15.5$, the preBötC begins to oscillate and rhythmically couples to the $\mathrm{pF}_{\mathrm{L}}$. In postnatal rats, glutamatergic $\mathrm{pF}_{\mathrm{L}}$ neurons provide excitatory drive to the preBötC, while the preBötC, in turn, provides inhibitory and excitatory influences on different subsets of $\mathrm{pF}_{\mathrm{L}}$ neurons ${ }^{92,93}$. In the in vivo adult rat, the preBötC can generate an inspiratory rhythm in the absence of $\mathrm{pF}_{\mathrm{L}}$ active expiratory activity ${ }^{14,94}$. However, in the converse situation, in order for the $\mathrm{pF}_{\mathrm{L}}$ to be active, a second low level of activity is simultaneously required: either activity from the preBötC or increased chemosensory drive ${ }^{94}$. Thus, the $\mathrm{pF}_{\mathrm{L}}$ drives active expiration, but another source of excitation is required for the network to be rhythmically active.
Neurons in the $\mathrm{pF}_{\mathrm{L}}$ are excitatory ${ }^{35,76}$ and do not express inhibitory biomarkers ${ }^{95,96}$. Therefore, any inhibitory action associated with $\mathrm{pF}_{\mathrm{L}}$ activity must be occurring through an intermediate relay of neurons, perhaps from the preBöt $\mathrm{C}^{48}$. Even excitatory projections from the preBötC to the $\mathrm{pF}_{\mathrm{L}}$ appear to be indirect and require an intermediate relay. Neurons in the preBötC send projections rostrally to an area adjacent to the $\mathrm{pF}_{\mathrm{L}}$, the ventral parafacial nucleus, or $\mathrm{pF}_{\mathrm{V}}{ }^{97}$, which has been shown to provide drive to expiration ${ }^{14,98}$, and could be functioning as the intermediate relay ${ }^{94}$. While the preBötC and $\mathrm{pF}_{\mathrm{L}}$ are anatomically distinct and functionally separate oscillators, the preBötC appears to be dominant, while $\mathrm{pF}_{\mathrm{L}}$ activity is conditional and absent at rest.

In contrast, inspiration and post-inspiration are active at rest $^{74}$, suggesting that this activity may reflect the interaction between anatomically and functionally distinct oscillators, preBötC and $\mathrm{PiCo}^{15}$. Horizontal slice population recordings of the preBötC and PiCo progressively synchronize when a $\mathrm{GABA}_{\mathrm{A}}$ receptor antagonist is applied to the slice. This observation suggests that GABAergic connections between the preBötC and PiCo help to coordinate the timing and phasing of the respiratory rhythms.

Light stimulation of channelrhodopsin-expressing Dbx1 neurons in the preBötC simultaneously evokes inspiratory population activity in the contralateral preBötC and hyperpolarizes a postinspiratory PiCo neuron ${ }^{15}$. However, when this experiment is repeated in the absence of inhibition, light stimulation now both activates an inspiratory population burst and depolarizes the PiCo neuron. Taken together, these results suggest that, under baseline conditions, the preBötC imparts an inhibitory influence on PiCo. However, when inhibition is blocked, it unmasks a concurrent excitatory influence of preBötC onto PiCo.

This work lays the foundation for beginning to understand the dynamic interplay between the three independent rhythm generators. In particular, further studies are needed that probe the interactions between the $\mathrm{pF}_{\mathrm{L}}$ and PiCo.

\section{Conclusion}

Reduced preparations that isolate respiratory microcircuits have led to a tremendous understanding of respiratory rhythm generation. Yet, with the availability of ever-more-advanced techniques such as computational modeling, access to transgenic animals, and the possibility of working in intact, alert animals, we will further progress in the unraveling of complex mechanisms.

One of the most established theories for the generation of respiratory rhythms is the dual oscillator hypothesis, which posits that inspiration and expiration are generated by alternating activity between preBötC and RTN/pFRG oscillators and post-inspiration is merely a motor subcomponent of expiration ${ }^{62,73}$. We propose a triple oscillator hypothesis or that the three phases of breathing in mammals - inspiration, post-inspiration, and active expiration - are generated by anatomically distinct excitatory rhythm generators: the preBötC, $\mathrm{PiCo}$, and the $\mathrm{pF}_{\mathrm{L}}$, respectively (Figure 2). It is interesting to note that three rhythm-generating networks have been hypothesized in the bullfrog ${ }^{2,99}$. 


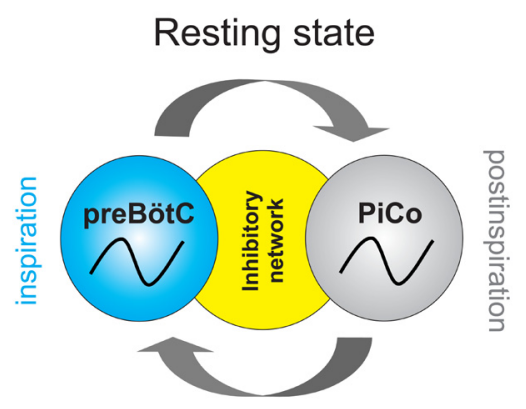

\section{High metabolic state}

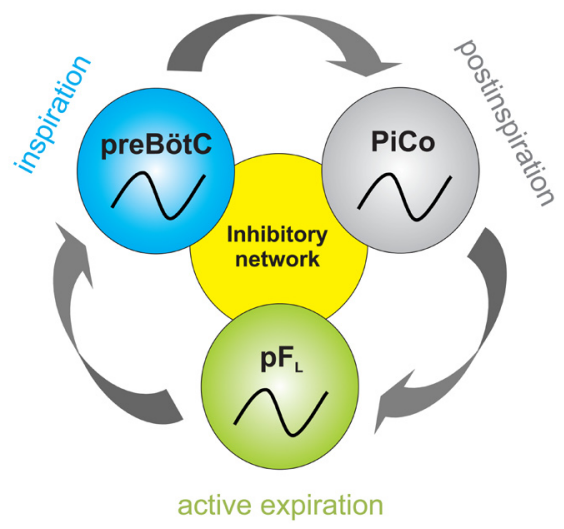

Figure 2. Illustration of triple-oscillator hypothesis. We propose that, at rest, the preBötzinger complex (preBötC) and post-inspiratory complex (PiCo) alternate activity to generate a two-phase rhythm, inspiration and post-inspiration. Under periods of high metabolic demand, for instance during exercise, a third oscillator is incorporated to create a three-phase rhythm. We propose that each of the three phases - inspiration, post-inspiration, and active expiration - are controlled by independent oscillators: the preBötC, PiCo, and lateral parafacial nucleus $\left(\mathrm{pF}_{\mathrm{L}}\right)$, respectively. We further postulate that inhibition between these networks coordinates the phasing and timing of the rhythms.

Many questions remain, however. Is there a hierarchical relationship between the three oscillators, i.e. is the preBötC the "mother of all respiratory rhythms"? Similar to the reconfiguration of the preBötC network in the generation of eupnea, gasps, and sighs, does the PiCo reconfigure to help generate post-inspiratory behaviors such as vocalization, swallowing, breath-holding, and coughing? Are the preBötC and/or PiCo networks impaired when patients with neurodegenerative disorders fail to coordinate breathing and swallowing and subsequently develop aspiration pneumonia ${ }^{100-103}$ ? Do homologous networks for PiCo and $\mathrm{pF}_{\mathrm{L}}$ exist in humans? While substantial work remains to be accomplished, we hope that core concepts garnered from the study of the control of respiration could lead to the discovery of mechanisms that universally underlie other oscillatory networks and, ultimately, to therapies for patients with centrally derived respiratory disorders.

\section{Competing interests}

The authors declare that they have no competing interests.

\section{Grant information}

The author(s) declared that no grants were involved in supporting this work.
1. Watson BO, Buzsáki G: Sleep, Memory \& Brain Rhythms. Daedalus. 2015; 144(1): 67-82.

PubMed Abstract | Publisher Full Text | Free Full Text

2. Ramirez JM, Dashevskiy T, Marlin IA, et al:: Microcircuits in respiratory rhythm generation: commonalities with other rhythm generating networks and evolutionary perspectives. Curr Opin Neurobiol. 2016; 41: 53-61. PubMed Abstract | Publisher Full Text

3. $\mathrm{F}$ Kiehn O: Decoding the organization of spinal circuits that control 
locomotion. Nat Rev Neurosci. 2016; 17(4): 224-38.

PubMed Abstract | Publisher Full Text | Free Full Text | F1000 Recommendation

4. F Grillner S, El Manira A: The intrinsic operation of the networks that make us locomote. Curr Opin Neurobiol. 2015; 31: 244-9.

PubMed Abstract | Publisher Full Text | F1000 Recommendation

5. Destexhe A: Modelling corticothalamic feedback and the gating of the thalamus by the cerebral cortex. J Physiol Paris. 2000; 94(5-6): 391-410. PubMed Abstract | Publisher Full Text

6. $\quad F$ Ketz NA, Jensen O, O'Reilly RC: Thalamic pathways underlying prefrontal cortex-medial temporal lobe oscillatory interactions. Trends Neurosci. 2015; 38(1): 3-12.

PubMed Abstract | Publisher Full Text | F1000 Recommendation

7. F Cheron G, Márquez-Ruiz J, Dan B: Oscillations, Timing, Plasticity, and Learning in the Cerebellum. Cerebellum. 2016; 15(2): 122-38. PubMed Abstract | Publisher Full Text | F1000 Recommendation

8. Llinás RR: The olivo-cerebellar system: a key to understanding the functional significance of intrinsic oscillatory brain properties. Front Neural Circuits. 2014 7: 96.

PubMed Abstract | Publisher Full Text | Free Full Text

9. Robinson I, Reddy AB: Molecular mechanisms of the circadian clockwork in mammals. FEBS Lett. 2014; 588(15): 2477-83.

PubMed Abstract | Publisher Full Tex

10. F Rosenwasser AM, Turek FW: Neurobiology of Circadian Rhythm Regulation. Sleep Med Clin. 2015; 10(4): 403-12.

PubMed Abstract | Publisher Full Text | F1000 Recommendation

11. Smith JC, Ellenberger $\mathrm{HH}$, Ballanyi $\mathrm{K}$, et al:: Pre-Bötzinger complex: a brainstem region that may generate respiratory rhythm in mammals. Science. 1991; 254(5032): 726-9.

PubMed Abstract | Publisher Full Text | Free Full Text

12. Ruangkittisakul A, Kottick A, Picardo MC, et al.: Identification of the pre-Bötzinger complex inspiratory center in calibrated "sandwich" slices from newborn mice with fluorescent Dbx1 interneurons. Physiol Rep. 2014; 2(8): pii: e12111. PubMed Abstract | Publisher Full Text | Free Full Text

13. F Pagliardini S, Janczewski WA, Tan W, et al:: Active expiration induced by excitation of ventral medulla in adult anesthetized rats. J Neurosci. 2011; 31(8): 2895-905.

PubMed Abstract | Publisher Full Text | Free Full Text | F1000 Recommendation

14. Huckstepp RT, Cardoza KP, Henderson LE, et al.: Role of parafacial nuclei in control of breathing in adult rats. J Neurosci. 2015; 35(3): 1052-67. PubMed Abstract | Publisher Full Text | Free Full Text

15. F Anderson TM, Garcia AJ 3rd, Baertsch NA, et al:: A novel excitatory network for the control of breathing. Nature. 2016; 536(7614): 76-80.

PubMed Abstract | Publisher Full Text | F1000 Recommendation

16. Ramirez JM, Quellmalz UJ, Richter DW: Postnatal changes in the mammalian respiratory network as revealed by the transverse brainstem slice of mice. J Physiol. 1996; 491(Pt 3): 799-812.

PubMed Abstract | Publisher Full Text | Free Full Text

17. Barnes BJ, Tuong CM, Mellen NM: Functional imaging reveals respiratory network activity during hypoxic and opioid challenge in the neonate rat tilted sagittal slab preparation. J Neurophysiol. 2007; 97(3): 2283-92. PubMed Abstract | Publisher Full Text

18. F Smith JC, Abdala AP, Koizumi H, et al:: Spatial and functional architecture of the mammalian brain stem respiratory network: a hierarchy of three oscillatory mechanisms. J Neurophysiol. 2007; 98(6): 3370-87.

PubMed Abstract | Publisher Full Text | Free Full Text | F1000 Recommendation

19. Richter DW: Generation and maintenance of the respiratory rhythm. J Exp Biol. 1982; 100: 93-107.

PubMed Abstract

20. Richter DW, Ballanyi K, Schwarzacher S: Mechanisms of respiratory rhythm generation. Curr Opin Neurobiol. 1992; 2(6): 788-93.

PubMed Abstract | Publisher Full Text

21. F Muere C, Neumueller S, Olesiak S, et al:: Combined unilateral blockade of cholinergic, peptidergic, and serotonergic receptors in the ventral respiratory column does not affect breathing in awake or sleeping goats. $J$ Appl Physiol (1985). 2015; 119(3): 308-20.

PubMed Abstract | Publisher Full Text | Free Full Text | F1000 Recommendation

22. F Gourévitch B, Mellen N: The preBötzinger complex as a hub for network activity along the ventral respiratory column in the neonate rat. Neuroimage. 2014; 98: 460-74.

PubMed Abstract | Publisher Full Text | F1000 Recommendation

23. Raghuraman S, Garcia AJ, Anderson TM, et al:: Defining modulatory inputs into CNS neuronal subclasses by functional pharmacological profiling. Proc Natl Acad Sci U S A. 2014; 111(17): 6449-54 PubMed Abstract | Publisher Full Text | Free Full Text

24. $\mathrm{F}$ Tan W, Janczewski WA, Yang $\mathrm{P}$, et al.: Silencing preBötzinger complex somatostatin-expressing neurons induces persistent apnea in awake rat. Nat Neurosci. 2008; 11(5): 538-40.

PubMed Abstract | Publisher Full Text | Free Full Text | F1000 Recommendation

25. Gray PA, Hayes JA, Ling GY, et al.: Developmental origin of preBötzinger complex respiratory neurons. J Neurosci. 2010; 30(44): 14883-95. PubMed Abstract | Publisher Full Text | Free Full Text

26. Ramirez JM, Schwarzacher SW, Pierrefiche O, et al.: Selective lesioning of the cat pre-Bötzinger complex in vivo eliminates breathing but not gasping. J Physiol. 1998; 507(Pt 3): 895-907.

PubMed Abstract | Publisher Full Text | Free Full Text

27. Johnson SM, Koshiya N, Smith JC: Isolation of the kernel for respiratory rhythm generation in a novel preparation: the pre-Bötzinger complex "island". J Neurophysiol. 2001; 85(4): 1772-6.

PubMed Abstract

28. Lieske SP, Thoby-Brisson M, Telgkamp P, et al:: Reconfiguration of the neura network controlling multiple breathing patterns: eupnea, sighs and gasps [see comment]. Nat Neurosci. 2000; 3(6): 600-7.

PubMed Abstract | Publisher Full Text

29. Ramirez JM, Richter DW: The neuronal mechanisms of respiratory rhythm generation. Curr Opin Neurobiol. 1996; 6(6): 817-25.

PubMed Abstract | Publisher Full Text

30. F Schwarzacher SW, Rüb U, Deller T: Neuroanatomical characteristics of the human pre-Bötzinger complex and its involvement in neurodegenerative brainstem diseases. Brain. 2011; 134(Pt 1): 24-35. PubMed Abstract | Publisher Full Text | F1000 Recommendation

31. $\quad F$ Bouvier J, Thoby-Brisson M, Renier N, et al.: Hindbrain interneurons and axon guidance signaling critical for breathing. Nat Neurosci. 2010; 13(9): 1066-74.

PubMed Abstract | Publisher Full Text | F1000 Recommendation

32. Ruangkittisakul A, Schwarzacher SW, Secchia L, et al.: High sensitivity to neuromodulator-activated signaling pathways at physiological $\left[\mathrm{K}^{+}\right]$of confocally imaged respiratory center neurons in on-line-calibrated newborn rat brainstem slices. J Neurosci. 2006; 26(46): 11870-80.

PubMed Abstract | Publisher Full Text

33. Ruangkittisakul A, Panaitescu B, Ballanyi $\mathrm{K}: \mathbf{K}^{+}$and $\mathrm{Ca}^{2+}$ dependence of inspiratory-related rhythm in novel "calibrated" mouse brainstem slices. Respir Physiol Neurobiol. 2011; 175(1): 37-48.

PubMed Abstract | Publisher Full Text

34. Smith JC, Feldman JL: In vitro brainstem-spinal cord preparations for study of motor systems for mammalian respiration and locomotion. $J$ Neurosci Methods. 1987; 21(2-4): 321-33.

PubMed Abstract | Publisher Full Text

35. F Thoby-Brisson M, Karlén M, Wu N, et al.: Genetic identification of an embryonic parafacial oscillator coupling to the preBötzinger complex. Nat Neurosci. 2009; 12(8): 1028-35.

PubMed Abstract | Publisher Full Text | F1000 Recommendation

36. Paton JF: A working heart-brainstem preparation of the mouse. $J$ Neurosci Methods. 1996; 65(1): 63-8.

PubMed Abstract | Publisher Full Text

37. Mellen NM, Mishra D: Functional anatomical evidence for respiratory rhythmogenic function of endogenous bursters in rat medulla. $J$ Neurosci. 2010; 30(25): 8383-92.

PubMed Abstract | Publisher Full Text | Free Full Text

38. F Peña F, Parkis MA, Tryba AK, et al:: Differential contribution of pacemaker properties to the generation of respiratory rhythms during normoxia and hypoxia. Neuron. 2004; 43(1): 105-17. PubMed Abstract | Publisher Full Text | F1000 Recommendation

39. Ramirez JM, Doi A, Garcia AJ 3rd, et al.: The cellular building blocks of breathing. Compr Physiol. 2012; 2(4): 2683-731.

PubMed Abstract | Publisher Full Text | Free Full Text

40. Ramirez JM, Koch H, Garcia AJ 3rd, et al:: The role of spiking and bursting pacemakers in the neuronal control of breathing. J Biol Phys. 2011; 37(3): 241-61.

PubMed Abstract | Publisher Full Text | Free Full Text

41. Koch H, Garcia AJ 3rd, Ramirez JM: Network reconfiguration and neuronal plasticity in rhythm-generating networks. Integr Comp Biol. 2011; 51(6): 856-68. PubMed Abstract | Publisher Full Text | Free Full Text

42. Garcia AJ 3rd, Zanella S, Koch H, et al.: Chapter 3--networks within networks: the neuronal control of breathing. Prog Brain Res. 2011; 188: 31-50. PubMed Abstract | Publisher Full Text | Free Full Text

43. Peña F: Contribution of pacemaker neurons to respiratory rhythms generation in vitro. Adv Exp Med Biol. 2008; 605: 114-8.

PubMed Abstract | Publisher Full Text

44. Ramirez JM, Tryba AK, Peña F: Pacemaker neurons and neuronal networks: an integrative view. Curr Opin Neurobiol. 2004; 14(6): 665-74.

PubMed Abstract | Publisher Full Text

45. Del Negro CA, Morgado-Valle C, Hayes JA, et al:: Sodium and calcium currentmediated pacemaker neurons and respiratory rhythm generation. $J$ Neurosci. 2005; 25(2): 446-53.

PubMed Abstract | Publisher Full Text

46. Thoby-Brisson M, Ramirez JM: Identification of two types of inspiratory pacemaker neurons in the isolated respiratory neural network of mice. J Neurophysiol. 2001; 86(1): 104-12.

PubMed Abstract

47. Feldman JL, Del Negro CA, Gray PA: Understanding the rhythm of breathing: so 
near, yet so far. Annu Rev Physiol. 2013; 75: 423-52. PubMed Abstract | Publisher Full Text | Free Full Text

48. Morgado-Valle C, Baca SM, Feldman JL: Glycinergic pacemaker neurons in preBötzinger complex of neonatal mouse. J Neurosci. 2010; 30(10): 3634-9. PubMed Abstract | Publisher Full Text | Free Full Text

49. Peña F, Ramirez JM: Substance P-mediated modulation of pacemaker properties in the mammalian respiratory network. J Neurosci. 2004; 24(34): 7549-56.

PubMed Abstract | Publisher Full Text

50. Peña F, Aguileta MA: Effects of riluzole and flufenamic acid on eupnea and gasping of neonatal mice in vivo. Neurosci Lett. 2007; 415(3): 288-93. PubMed Abstract | Publisher Full Text

51. Ramirez JM, Garcia A 3rd: Point: Medullary pacemaker neurons are essential for both eupnea and gasping in mammals. J Appl Physiol (1985). 2007; 103(2): 717-8; discussion 722 .

PubMed Abstract | Publisher Full Text

52. Mellen NM, Thoby-Brisson M: Respiratory circuits: development, function and models. Curr Opin Neurobiol. 2012; 22(4): 676-85. PubMed Abstract | Publisher Full Text

53. Carroll MS, Ramirez JM: Cycle-by-cycle assembly of respiratory network activity is dynamic and stochastic. J Neurophysiol. 2013; 109(2): 296-305. PubMed Abstract | Publisher Full Text | Free Full Text

54. Purvis LK, Smith JC, Koizumi H, et al.: Intrinsic bursters increase the robustness of rhythm generation in an excitatory network. J Neurophysiol. 2007; 97(2): 1515-26.

PubMed Abstract | Publisher Full Text

55. Tryba AK, Peña F, Ramirez JM: Stabilization of bursting in respiratory pacemaker neurons. J Neurosci. 2003; 23(8): 3538-46. PubMed Abstract

56. Tryba AK, Ramirez JM: Background sodium current stabilizes bursting in respiratory pacemaker neurons. $J$ Neurobiol. 2004; 60(4): 481-9. PubMed Abstract | Publisher Full Text

57. Koizumi $\mathrm{H}$, Smith JC: Persistent $\mathrm{Na}^{+}$and $\mathbf{K}^{+}$-dominated leak currents contribute to respiratory rhythm generation in the pre-Bötzinger complex in vitro. $J$ Neurosci. 2008; 28(7): 1773-85. PubMed Abstract | Publisher Full Text

58. Purvis LK, Butera RJ: lonic current model of a hypoglossal motoneuron. J Neurophysiol. 2005; 93(2): 723-33. PubMed Abstract | Publisher Full Text

59. Del Negro CA, Koshiya N Butera RJ Jr, et al: Persistent sodium current, membrane properties and bursting behavior of pre-bötzinger complex inspiratory neurons in vitro. $J$ Neurophysiol. 2002; 88(5): 2242-50. PubMed Abstract | Publisher Full Text

60. Rybak IA, Ptak K, Shevtsova NA, et al:: Sodium currents in neurons from the rostroventrolateral medulla of the rat. J Neurophysiol. 2003; 90(3): 1635-42. PubMed Abstract | Publisher Full Text

61. Rubin JE, Hayes JA, Mendenhall JL, et al:: Calcium-activated nonspecific cation current and synaptic depression promote network-dependent burst oscillations. Proc Natl Acad Sci U S A. 2009; 106(8): 2939-44. PubMed Abstract | Publisher Full Text | Free Full Text

62. Feldman JL, Del Negro CA: Looking for inspiration: new perspectives on respiratory rhythm. Nat Rev Neurosci. 2006; 7(3): 232-42. PubMed Abstract | Publisher Full Text | Free Full Text

63. Carroll MS, Viemari JC, Ramirez JM: Patterns of inspiratory phase-dependent activity in the in vitro respiratory network. J Neurophysiol. 2013; 109(2): 285-95. PubMed Abstract | Publisher Full Text | Free Full Text

64. Nieto-Posadas A, Flores-Martínez E, Lorea-Hernández JJ, et al:: Change in network connectivity during fictive-gasping generation in hypoxia: prevention by a metabolic intermediate. Front Physiol. 2014; 5: 265. PubMed Abstract | Publisher Full Text | Free Full Text

65. Rekling JC, Shao XM, Feldman JL: Electrical coupling and excitatory synaptic transmission between rhythmogenic respiratory neurons in the preBötzinger complex. J Neurosci. 2000; 20(23): RC113. PubMed Abstract | Free Full Text

66. F Kam K, Worrell JW, Janczewski WA, et al.: Distinct inspiratory rhythm and pattern generating mechanisms in the preBötzinger complex. J Neurosci. 2013; 33(22): 9235-45

PubMed Abstract | Publisher Full Text | Free Full Text | F1000 Recommendation

67. Cui Y, Kam K, Sherman D, et al.: Defining preBötzinger Complex Rhythm- and Pattern-Generating Neural Microcircuits In Vivo. Neuron. 2016; 91(3): 602-14. PubMed Abstract | Publisher Full Text | Free Full Text

68. McCrea DA, Rybak IA: Organization of mammalian locomotor rhythm and pattern generation. Brain Res Rev. 2008; 57(1): 134-46. PubMed Abstract | Publisher Full Text | Free Full Text

69. Dick TE, Dutschmann M, Feldman JL, et al.: Facts and challenges in respiratory neurobiology. Respir Physiol Neurobiol. 2015; pii: S1569-9048(15)00027-0. PubMed Abstract | Publisher Full Text | Free Full Text

70. Marchenko V, Koizumi H, Mosher B, et al:: Perturbations of Respiratory Rhythm and Pattern by Disrupting Synaptic Inhibition within Pre-Bötzinger and Bötzinger Complexes. eNeuro. 2016; 3(2): pii: ENEURO.0011-16.2016. PubMed Abstract | Publisher Full Text | Free Full Text
71. Ezure K: Synaptic connections between medullary respiratory neurons and considerations on the genesis of respiratory rhythm. Prog Neurobiol. 1990; 35(6): 429-50

PubMed Abstract | Publisher Full Text

72. Paton JF, Ramirez JM, Richter DW: Functionally intact in vitro preparation generating respiratory activity in neonatal and mature mammals. Pflugers Arch 1994; 428(3-4): 250-60.

PubMed Abstract | Publisher Full Text

73. F Janczewski WA, Feldman JL: Distinct rhythm generators for inspiration and expiration in the juvenile rat. $J$ Physiol. 2006; 570(Pt 2): 407-20.

PubMed Abstract | Publisher Full Text | Free Full Text | F1000 Recommendation

74. Mörschel M, Dutschmann M: Pontine respiratory activity involved in inspiratory/ expiratory phase transition. Philos Trans R Soc Lond B Biol Sci. 2009; 364(1529): 2517-26.

PubMed Abstract | Publisher Full Text | Free Full Text

75. Krause KL, Forster HV, Kiner T, et al:: Normal breathing pattern and arterial blood gases in awake and sleeping goats after near total destruction of the presumed pre-Botzinger complex and the surrounding region. J Appl Physiol (1985). 2009; 106(2): 605-19.

PubMed Abstract | Publisher Full Text | Free Full Text

76. Onimaru $\mathrm{H}, \mathrm{Homma} \mathrm{I}$ : Two modes of respiratory rhythm generation in the newborn rat brainstem-spinal cord preparation. Adv Exp Med Biol. 2008; 605: 104-8.

PubMed Abstract | Publisher Full Text

77. Onimaru $\mathrm{H}$, Ikeda $\mathrm{K}$, Kawakami $\mathrm{K}$ : $\mathrm{CO}_{2}$-sensitive preinspiratory neurons of the parafacial respiratory group express Phox $2 \mathrm{~b}$ in the neonatal rat. $J$ Neurosci. 2008; 28(48): 12845-50.

PubMed Abstract | Publisher Full Text

78. Burns BD: The central control of respiratory movements. Br Med Bull. 1963; 19 $7-9$

PubMed Abstract

79. Smith JC, Abdala AP, Rybak IA, et al:: Structural and functional architecture of respiratory networks in the mammalian brainstem. Philos Trans $R$ Soc Lond $B$ Biol Sci. 2009; 364(1529): 2577-87.

PubMed Abstract | Publisher Full Text | Free Full Text

80. Ezure K, Tanaka I, Kondo M: Glycine is used as a transmitter by decrementing expiratory neurons of the ventrolateral medulla in the rat. $J$ Neurosci. 2003;

23(26): 8941-8.

PubMed Abstract

81. Merrill EG, Fedorko L: Monosynaptic inhibition of phrenic motoneurons: a long descending projection from Bötzinger neurons. J Neurosci. 1984; 4(9): 2350-3. PubMed Abstract

82. Winter SM, Fresemann J, Schnell C, et al:: Glycinergic interneurons are functionally integrated into the inspiratory network of mouse medullary slices. Pflugers Arch. 2009; 458(3): 459-69.

PubMed Abstract | Publisher Full Text | Free Full Text

83. Richter A, Heyne K, Sagebiel J, et al:: Respiratorischer Notfall beim Neugeborenen: extreme laryngo-tracheo-oesophageale Spalte (OesophagoTrachea). Monatsschr Kinderheilkd. 1986; 134: 874-7.

84. F Richter DW, Smith JC: Respiratory rhythm generation in vivo. Physiology (Bethesda). 2014; 29(1): 58-71.

PubMed Abstract | Publisher Full Text | Free Full Text | F1000 Recommendation

85. Smith JC, Abdala AP, Borgmann A, et al.: Brainstem respiratory networks building blocks and microcircuits. Trends Neurosci. 2013; 36(3): 152-62. PubMed Abstract | Publisher Full Text | Free Full Text

86. Janczewski WA, Tashima A, Hsu P, et al.: Role of inhibition in respiratory pattern generation. $J$ Neurosci. 2013; 33(13): 5454-65.

PubMed Abstract | Publisher Full Text | Free Full Text

87. Burke PG, Abbott SB, McMullan S, et al:: Somatostatin selectively ablates postinspiratory activity after injection into the Bötzinger complex. Neuroscience. 2010; 167(2): 528-39.

PubMed Abstract | Publisher Full Text

88. Ramirez JM, Quellmalz UJ, Wilken B, et al.: The hypoxic response of neurones within the in vitro mammalian respiratory network. $J$ Physiol. 1998; 507(Pt 2): 571-82.

PubMed Abstract | Publisher Full Text | Free Full Text

89. Brockhaus J, Ballanyi K: Synaptic inhibition in the isolated respiratory network of neonatal rats. Eur J Neurosci. 1998; 10(12): 3823-39. PubMed Abstract | Publisher Full Text

90. Ren J, Greer JJ: Modulation of respiratory rhythmogenesis by chloridemediated conductances during the perinatal period. J Neurosci. 2006; 26(14): 3721-30

PubMed Abstract | Publisher Full Text

91. Shao XM, Feldman JL: Respiratory rhythm generation and synaptic inhibition of expiratory neurons in pre-Bötzinger complex: differential roles of glycinergic and GABAergic neural transmission. J Neurophysiol. 1997; 77(4): 1853-60.

PubMed Abstract

92. Onimaru H, Ikeda K, Kawakami K: Defective interaction between dual oscillators for respiratory rhythm generation in $\mathrm{Na}^{+}, \mathrm{K}^{+}$-ATPase $\alpha 2$ subunit-deficient mice. J Physiol. 2007; 584(pt 1): 271-84.

PubMed Abstract | Publisher Full Text | Free Full Text 
93. Takeda S, Eriksson LI, Yamamoto Y, et al:: Opioid action on respiratory neuron activity of the isolated respiratory network in newborn rats. Anesthesiology. 2001; 95(3): 740-9.

PubMed Abstract | Publisher Full Text

94. F Huckstepp RT, Henderson LE, Cardoza KP, et al:: Interactions between respiratory oscillators in adult rats. eLife. 2016; 5: pii: e14203.

PubMed Abstract | Publisher Full Text | Free Full Text | F1000 Recommendation

95. Tanaka I, Ezure K, Kondo M: Distribution of glycine transporter 2 mRNAcontaining neurons in relation to glutamic acid decarboxylase mRNAcontaining neurons in rat medulla. Neurosci Res. 2003; 47(2): 139-51. PubMed Abstract | Publisher Full Text

96. Ellenberger HH: Distribution of bulbospinal gamma-aminobutyric acidsynthesizing neurons of the ventral respiratory group of the rat. J Comp Neurol. 1999; 411(1): 130-44. PubMed Abstract | Publisher Full Text

97. Tan W, Pagliardini S, Yang P, et al.: Projections of preBötzinger complex neurons in adult rats. $J$ Comp Neurol. 2010; 518(10): 1862-78. PubMed Abstract | Publisher Full Text | Free Full Text

98. Silva JN, Tanabe FM, Moreira TS, et al.: Neuroanatomical and physiologica evidence that the retrotrapezoid nucleus/parafacial region regulates expiration in adult rats. Respir Physiol Neurobiol. 2016; 227: 9-22. PubMed Abstract | Publisher Full Text

99. $\quad \mathrm{F}$ Baghdadwala MI, Duchcherer M, Paramonov J, et al:: Three brainstem areas involved in respiratory rhythm generation in bullfrogs. $J$ Physiol. 2015; 593(13): 2941-54.

PubMed Abstract | Publisher Full Text | Free Full Text | F1000 Recommendation

100. Alagiakrishnan K, Bhanji RA, Kurian M: Evaluation and management of oropharyngeal dysphagia in different types of dementia: a systematic review. Arch Gerontol Geriatr. 2013; 56(1): 1-9.

PubMed Abstract | Publisher Full Text

101. Easterling CS, Robbins E: Dementia and dysphagia. Geriatr Nurs. 2008; 29(4): 275-85. PubMed Abstract | Publisher Full Text

102. Lin CW, Chang YC, Chen WS, et al:: Prolonged swallowing time in dysphagic Parkinsonism patients with aspiration pneumonia. Arch Phys Med Rehabil. 2012; 93(11): 2080-4.

PubMed Abstract | Publisher Full Text

103. Kalia M: Dysphagia and aspiration pneumonia in patients with Alzheimer's disease. Metabolism. 2003; 52(10 Suppl 2): 36-8.

PubMed Abstract | Publisher Full Text 


\section{Open Peer Review}

\section{Current Peer Review Status:}

\section{Editorial Note on the Review Process}

Faculty Reviews are review articles written by the prestigious Members of Faculty Opinions. The articles are commissioned and peer reviewed before publication to ensure that the final, published version is comprehensive and accessible. The reviewers who approved the final version are listed with their names and affiliations.

\section{The reviewers who approved this article are:}

\section{Version 1}

\section{Richard Wilson}

Hotchkiss Brain Institute and Alberta Children's Hospital Research Institute, Department of Physiology and Pharmacology, Cumming School of Medicine, University of Calgary, Calgary, Alberta, Canada Competing Interests: No competing interests were disclosed.

2. Jose Fernando Pena-Ortega

Departamento de Neurobiología del Desarrollo y Neurofisiología, Instituto de Neurobiología, Universidad Nacional Autónoma de México-Campus Juriquilla, Querétaro, Mexico

Competing Interests: No competing interests were disclosed.

\section{Muriel Thoby-Brisson}

Institut de Neurosciences Cognitives et Intégratives d'Aquitaine, CNRS UMR 5287, Université de Bordeaux, Bordeaux, France

Competing Interests: No competing interests were disclosed.

The benefits of publishing with F1000Research:

- Your article is published within days, with no editorial bias

- You can publish traditional articles, null/negative results, case reports, data notes and more

- The peer review process is transparent and collaborative

- Your article is indexed in PubMed after passing peer review

- Dedicated customer support at every stage

For pre-submission enquiries, contact research@f1000.com 